\title{
Origin of the subepidermal tissue in Piper L. leaves
}

\author{
Nakamura, AT. ${ }^{a *}$, Simão, E. ${ }^{a}$, Silva, L. ${ }^{b}$ and Torres, GA. ${ }^{b}$ \\ anstituto de Ciências Agrárias - ICIAG, Universidade Federal de Uberlândia - UFU, Av. Goiás, 2000, \\ CEP 38500-000, Monte Carmelo, MG, Brazil \\ ${ }^{\text {b}}$ Departamento de Biologia - DBI, Universidade Federal de Lavras - UFLA, CP 3037 , \\ CEP 37200-000, Lavras, MG, Brazil \\ *e-mail: atnakamura@ufu.br
}

Received: July 25, 2013 - Accepted: January 06, 2014 - Distributed May 31, 2015

(With 2 figures)

\begin{abstract}
Studies on the anatomy of Piper leaves demonstrate the presence of a subepidermal tissue distinct from the adjacent epidermis, which cells show thin walls and hyaline contents. Some authors consider such cells a hypodermal tissue, while others refer to them as components of a multiple epidermis. In this study, the nature of this subepidermal tissue was investigated through the analysis of leaf ontogeny in three Piper species. The analysis showed that the referred tissue originates from the ground meristem and, thus, should be considered a hypodermis. The studied species suggests that the role of the hypodermis would be to protect the photosynthetic apparatus from excess light, regulating the intensity of light reaching the chlorophyll parenchyma.
\end{abstract}

Keywords: hypodermis, multisseriate epidermis, Piperaceae.

\section{Origem do tecido subepidérmico em folhas de Piper L.}

\section{Resumo}

Os estudos de anatomia foliar de espécies de Piper revelam a presença de um tecido subepidérmico distinto da epiderme e cujas células apresentam paredes finas e conteúdo hialino. Estas células são referenciadas por alguns autores como um tecido hipodérmico e por outros, como sendo constituintes de uma epiderme múltipla. Nesse estudo verificou-se a natureza deste tecido subepidérmico a partir da análise da ontogênese foliar de três espécies de Piper. A análise revelou que o referido tecido tem origem do meristema fundamental e, portanto, deve ser denominado de hipoderme. Para as espécies avaliadas, sugere-se que a hipoderme teria função de, proteger o aparato fotossintético do excesso de luminosidade, regulando a intensidade luminosa que atinge o parênquima clorofiliano.

Palavras-chave: hipoderme, epiderme multisseriada, Piperaceae.

\section{Introduction}

Piperaceae species present a multisseriate epidermis, according to Fahn (1974). Yet, for the five existing genera in this family (Stevens, 2013), the multisseriate epidermis is reported only in Peperomia species (Takemori et al., 2003; Evert, 2006), which show succulent leaves.

Subepidermal layers formed by conspicuous, hyaline cells were observed on the adaxial surface of another Piperaceae species, Ottonia martiana Miq.; in this species, the subepidermal tissue was also seen on the abaxial surface, but only next to the central rib of the leaf (Souza et al., 2004). In this case, the subepidermal tissue was not considered a part of the epidermis, neither a hypodermis, being emphasized that further studies on the leaf ontogeny were needed.

The dermal system of Piper leaves is usually described as formed by a unisseriate epidermis and the adjacent cell layers, called hypodermis (Yuncker, 1973; Vianna and Akisue, 1997; Nascimento and Vilhena-Potiguara, 1999; Cutter, 2002; Albiero et al., 2005a, b, 2006). In turn, some authors such as Gogosz et al. (2012) describe a multiple epidermis in the leaves of nine Piper species. At maturity, it is difficult to distinguish the multiple epidermis from the hypodermis and this controversy usually leads to the conclusion that studies on leaf ontogeny are needed.

An attempt to elucidate the discussion on the origin of subepidermal tissues was the observation by Albiero et al. (2005a) of rare divisions in the protodermis of Piper crassinervium H.B. \& K. leaves, suggesting the presence of a multisseriate epidermis. Although the authors could observe these divisions, they were not able to confirm the nature of the subepidermal tissue, since studies on leaf development were not conducted.

Under this scenario, this study aimed on clarifying the origin of the subepidermal layers of Piper L. leaves, through anatomical and ontogenetic analyses of Piper aduncum L., $P$. aff. hispidinervum and $P$. hispidinervum C.DC. leaves. 


\section{Material and Methods}

Stem apexes and leaf primordia of Piper aduncum, Piper aff. hispidinervum e Piper hispidinervum were collected at Departamento de Biologia, at Universidade Federal de Lavras, DBI-UFLA, where plants are cultivated in a greenhouse. These individuals are originated from EMBRAPA Acre (Rio Branco, Acre).

Botanical materials were fixed in Karnovsky's solution (Karnovsky, 1965) and stored in 70\% Ethyl Alcohol. Permanent slides were produced from the dehydration of materials in an ethanol series, and infiltration within hydroxyethyl methacrylate (Feder and O'Brien, 1968), following the manufacturer's instructions. Transverse $5 \mu \mathrm{m}$ sections were obtained with a rotation microtome, stained with $0.05 \%$ Toluidine Blue O (O'Brien et al., 1965), and mounted on Permount ${ }^{\mathrm{TM}}$.

Images were produced under a Carl Zeiss ${ }^{\mathrm{TM}}$ trinocular microscope, with an image capture device. Scales were projected under the same optical conditions.

\section{Results}

In the undifferentiated tissues of leaf primordia, the protodermis is unisseriate on both surfaces. Protodermal cells are cuboid to slightly elongated, radially (Figure 1a-e). Anticlinal and periclinal divisions are seen in this tissue, although they differentiate only into glandular (Figure 1b) and tector (Figure 1c) trichomes.

The ground meristem, located between the two protodermal surfaces, is formed of cells of varied shapes with high meristematic activity. On the adaxial surface, the ground meristem next to the protodermis shows periclinal divisions, specifically close to the leaf ribs (Figure 1a, c), although anticlinal divisions are more frequent (Figure 1b, $\mathrm{d}, \mathrm{e})$. At this developmental stage, some differentiating oil idioblasts are seen (Figure 1a, b, e).

Procambial rings, with more rectangular and diminute cells, are observed immersed in the ground meristem (Figure 1a, b, d, e).

At a later stage, young leaf, the epidermis become more radially elongated (Figure 2a-c) and it shows tector (Figure 2a-c) and glandular trichomes (Figure 2c).

In the mesophyll region, two cell layers differentiate next to the epidermis of the adaxial and abaxial surface, forming a tissue with hyaline, cuboid to radially elongated cells (Figure 2a-c).

The differentiation of the two cell layers on the upper surface, sometimes three layers (Figure 2c), and one a two cell layers on the lower surface are distinguished from the remaining layers of the ground meristem, especially seen through changes in cell shape and their hyaline contents. The cells from the meristematic layers, which will form the photosynthetic tissue, are isodiametric and show dense contents (Figure 2a-c). Collateral vascular bundles differentiate in this region (Figure 2a, c)

Mature leaves in the studied species are hypostomatic (Figure 2d) and present a unisseriate epidermis, with few tector and secretory trichomes. The subepidermal tissue, the hypodermis, of both surfaces presents typical parenchyma cells, with hyaline contents and thin walls. On the adaxial surface, the hypodermis varies from one to three layers of cells of varied shapes, from rectangular to isodiametric. On the abaxial surface, one to two layers are formed (Figure 2d-f).

The mesophyll is bilateral, showing palisade and spongy parenchyma; oil idioblasts (Figure 2d-f) and collateral vascular bundles are dispersed in this region.

\section{Discussion}

The hypodermis is characterized by the differentiation of cells originated from the ground meristem, while the multisseriate epidermis derives from periclinal divisions of the protodermis (Fahn, 1974). In the studied Piper species, periclinal divisions were observed in the protodermis, but these originated the epidermal annexes, not the subepidermal tissue; thus, the latter should be referred to

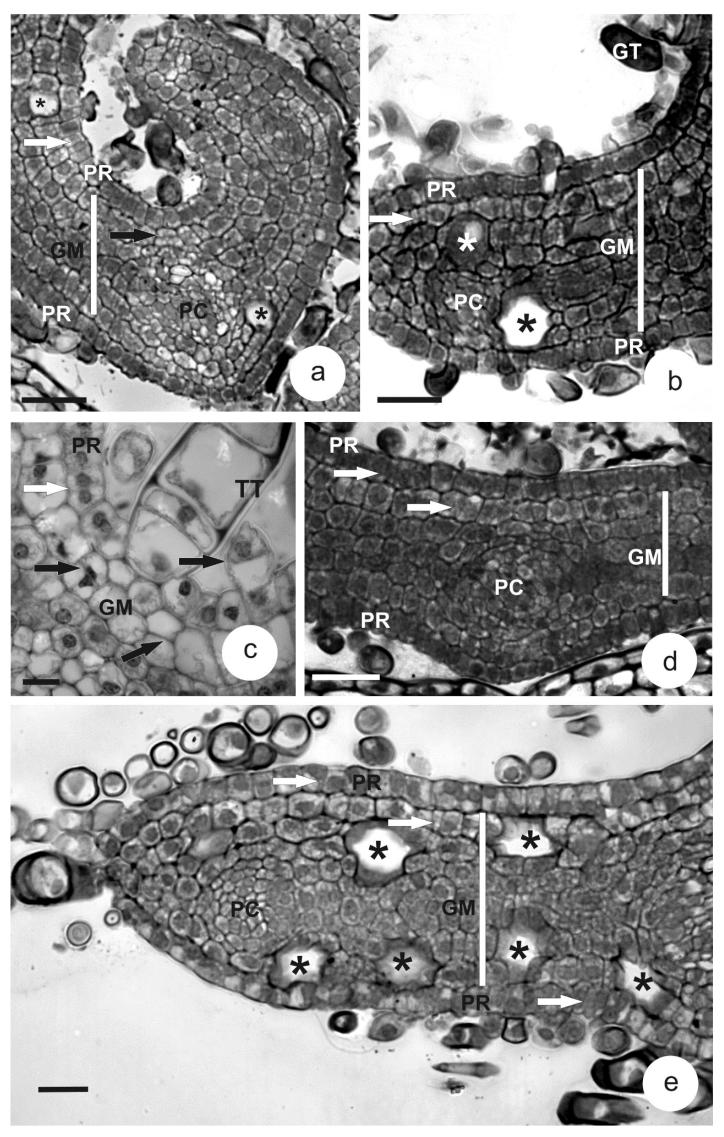

Figure 1. Transverse sections of leaf primordia in three Piper species. a-c. P. aduncum. d. P. aff. hispidinervum. e. $P$. hispidinervum. (BLACK ARROW = periclinal division; WHITE ARROW $=$ anticlinal division; $*=$ oil idioblast; $\mathrm{GM}=$ ground meristem; $\mathrm{GT}=$ glandular trichome; $\mathrm{HY}=$ hypodermis; $\mathrm{PC}=$ procambium; $\mathrm{PR}=$ protodermis; $\mathrm{TT}=$ tector trichome). Bars $=25 \mu \mathrm{m}(\mathrm{a}, \mathrm{b}, \mathrm{d}) ; 20 \mu \mathrm{m}(\mathrm{e})$; $10 \mu \mathrm{m}(\mathrm{c})$. 


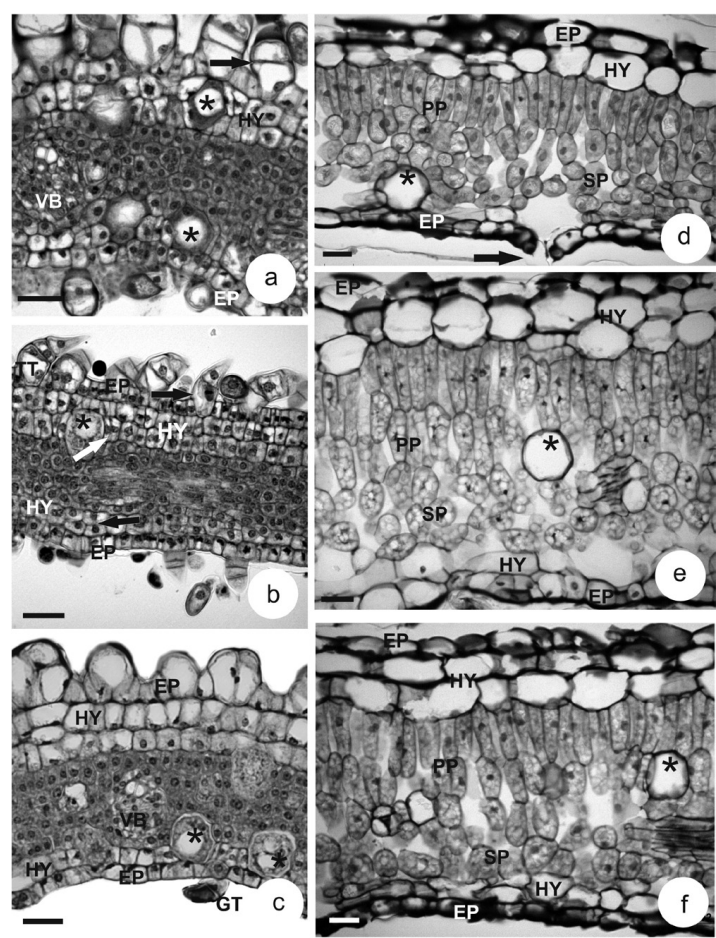

Figure 2. Transverse sections of Piper leaves. a-c. young leaves. d-f. mature leaves. a, d. P. aduncum; ARROW $=$ stomata. b, e. $P$. aff. hispidinervum. c, f. P. hispidinervum. ${ }^{*}=$ oil idioblast; $\mathrm{EP}=$ epidermis; $\mathrm{GT}=$ glandular trichome $\mathrm{HY}=$ hypodermis, $\mathrm{PP}=$ palisade parenchyma; $\mathrm{SP}=$ spongy parenchyma; $\mathrm{VB}=$ vascular bundle; BLACK ARROW: periclinal division; WHITE

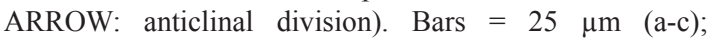
$50 \mu \mathrm{m}$ (d-f).

as a hypodermis. The rare periclinal divisions observed in the protodermal cells of Piper crassinervium H.B. \& K. leaves (Albiero et al., 2005a) demonstrate that the intensity of divisions is enough to form trichomes, but not a subepidermal tissue, confirming that the subepidermal tissue originates from the ground meristem, not from the protodermis.

The hypodermal tissue frequently occurs in more resistant leaves, with scleromorphic features, being usually absent in thin, flexible leaves, in addition to being found mainly next to the central rib of leaves (Mauseth, 1988). It is evident in this study that, although the analyzed Piper species show thin and flexible leaves, the hypodermis is present on both surfaces in a varied number of layers; furthermore, it can also differentiate into a collenchyma next to the central rib on adaxial leaf surfaces. The number of hypodermal layers is used by several authors as a taxonomic character to identify species in the genus (Albiero et al., 2005a, b, 2006; Gogosz et al., 2012; Raman et al., 2012).

Although the subepidermal tissue in Piper is originated from the ground meristem, for another genus in the Piperaceae, Peperomia, the analysis of leaf ontogeny demonstrated the presence of a multisseriate epidermis (Takemori et al., 2003). The difference in the origin of the subepidermal tissue in species of the same family may be related, in the case of Peperomia, to an evolutionary convergence to the epiphytic habit, as defended by Reginato et al. (2009). These authors report that species from different families and orders, with the same epiphytic habit, were subjected to a selective pressure to adapt to the environment, as exemplified by the presence of leaves with water reserves.

Reginato et al. (2009) also reported that the subepidermal tissues (hypodermis or multisseriate epidermis) in the succulent leaves of Peperomia, Pleiochton (Melastomataceae) and representatives of the Gesneriaceae, were related to water storage, occupying a great proportion of the leaf volume (between one third and half of it). The proportion of photosynthetic and water tissues, in addition to features such as homogeneous mesophylls with big, vacuolated cells, may also evidence a CAM photosynthetic metabolism (Smith and Winter, 1996 apud Reginato et al. 2009). Such an anatomical pattern is not seen in Piper species, although studies on their photosynthetic metabolism are still needed.

For Rudall (2007), the presence of a hypodermis may be a xeromorphic feature, as well as the presence of thick cuticles and epidermis, which in combination would diminish the light intensity reaching the photosynthetic tissue. Among the xeromorphic features reported by Rudall (2007), the presence of a hypodermis in Piper is always cited, although the other characteristics are most probably absent due to the environmental conditions to which Piper species are adapted: tropical forest environment. Although the species grow in the woods, their seeds germinate preferably in areas where the incidence of light is higher (Bergo et al., 2010; Pacheco Junior et al., 2013) such as edges and clearings. Because the leaves of Piper species are exposed to this increased luminosity, they are subject to the stress caused by excess of light. Additionally, environmental variations are larger in clearings and edges (Tabarelli and Mantovani, 1999), particularly with respect to light incidence, temperature and humidity, factors which directly influence the morphology of the leaves.

The studied Piper species present flexible, thin leaves, with hypodermis on both leaf surfaces (but more prominent on the adaxial surface), which occupy up to one fourth of the leaf. It is probable that the hyaline hypodermis of Piper aduncum, $P$. aff. hispidinervum and $P$. hispidinervum is related to their photosynthetic efficiency, as it would protect the photosynthetic apparatus from excess light, regulating light intensity as seen in the Bromeliaceae (Brighigna et al., 1984) and in Peperomia (Takemori et al., 2003). Although several authors report that the hypodermis may function as a protective tissue against the excessive solar radiation, this hypothesis should be tested physiologically.

\section{Conclusion}

The distinct subepidermal layers seen in the mature leaves of the studied Piper species are originated from the ground meristem. Therefore these layers should be referred as hypodermis. 


\section{Acknowledgements}

To EMBRAPA Acre, for the botanical materials used in the anatomical analyses. To the undergraduate student Beatriz Pereira Ezequiel, for the production of slides.

\section{References}

ALBIERO, ALM., PAOLI, AAS., SOUZA, LA. and MOURÃO, KSM., 2005a. Morfoanatomia dos órgãos vegetativos de Piper crassinervium HB \& K. (Piperaceae). Acta Botanica Brasilica, vol. 19 , no. 2, p. 305-312.

ALBIERO, ALM., SOUZA, LA., MOURÃO, KSM., ALMEIDA, OJG. and LOPES, WAL., 2005b. Morfo-anatomia do caule e da folha de Piper gaudichaudianum Kuntze (Piperaceae). Acta Farmaceutica Bonaerense, vol. 24, no. 4, p. 550-554.

ALBIERO, ALM., PAOLI, AAS., SOUZA, LA. and MOURÃO, KSM., 2006. Morfoanatomia dos órgãos vegetativos de Piper hispidum Sw. (Piperaceae). Revista Brasileira de Farmacognosia, vol. 16 , no. 3, p. 379-391.

BERGO, CL., SILVA, RC., OHLSON, OC., BIASI, LA. and PANOBIANCO, M., 2010. Luz e temperatura na germinação de sementes de pimenta longa (Piper hispidinervum) e pimentade-macaco (Piper aduncum). Revista Brasileira de Sementes, vol. 32, no. 3, p. 170-176. http://dx.doi.org/10.1590/S010131222010000300019 .

BRIGHIGNA, L., FIORDI, AC. and PALANDRI, MR., 1984. Structural characteristics of mesophyll in some Tillandsia species. Phytomorphology, vol. 34, p. 191-200.

CUTTER, EG., 2002. Anatomia vegetal: experimentos e interpretação. São Paulo: Roca. 336 p.

EVERT, RF., 2006. Esau's plant anatomy: meristems, cells, and tissues of the plant body: their structure, function, and development. 3rd ed. New Jersey: John Wiley \& Sons, Inc. 601 p.

FAHN, A., 1974. Plant anatomy. Oxford: Pergamon Press. 611 p.

FEDER, N. and O'BRIEN, TP., 1968. Plant microtechnique: some principles and new methods. American Journal of Botany, vol. 55, no. 1, p. 123-142. http://dx.doi.org/10.2307/2440500.

GOGOSZ, AM., BOEGER, MRT., NEGRELLE, RRB. and BERGO, C., 2012. Anatomia foliar comparativa de nove espécies do gênero Piper (Piperaceae). Rodriguesia, vol. 63, no. 2, p. 405-417. http://dx.doi.org/10.1590/S2175-78602012000200013.

KARNOVSKY, MJ., 1965. A formaldehyde-glutaraldehyde fixative of high osmolality for use in electron microscopy. The Journal of Cell Biology, vol. 27, p. 137-138.
MAUSETH, JD., 1988. Plant anatomy. California: Cummings Publishing Company. 560 p.

NASCIMENTO, ME. and VILHENA-POTIGUARA, VCR., 1999. Aspectos anatômicos dos órgãos vegetativos de Piper hispidinervium C. DC. (Piperaceae) e suas estruturas secretoras. Boletim do Museu Paraense Emílio Goeldi, vol. 15, no. 1, p. 39-104.

O'BRIEN, TP., FEDER, N. and MCCULLY, ME., 1965. Polychromatic staining of plant cell walls by toluidine blue $\mathrm{O}$. Protoplasma, vol. 59, p. 368-373.

PACHECO JUNIOR, F., SILVA, JB., NEGREIROS, JRS., SILVA, MRG. and FARIAS, SB., 2013. Germination and vigor of longpepper seeds (Piper hispidinervum) as a function of temperature and light. Revista Ciência Agronômica, vol. 44, no. 2, p. 325-333. http://dx.doi.org/10.1590/S1806-66902013000200015.

RAMAN, V., GALAL, AM. and KHAN, IA., 2012. An investigation of the vegetative anatomy of Piper sarmentosum, and a comparison with the anatomy of Piper betle (Piperaceae). American Journal of Plant Sciences, vol. 3, no. 8, p. 1135-1144. http://dx.doi.org/10.4236/ajps.2012.38137.

REGINATO, M., BOEGER, MRT. and GOLDENBERG, R., 2009. Comparative anatomy of the vegetative organs in Pleiochiton A. Gray (Melastomataceae), with emphasis on adaptations to epiphytism. Flora, vol. 204, no. 10, p. 782-790. http://dx.doi. org/10.1016/j.flora.2008.11.006.

RUDALL, PJ., 2007. Anatomy of flowering plants - an introduction to structure and development. 3nd ed. Cambridge: Cambridge University Press. 145 p.

SOUZA, LA., MOSCHETA IS. and OLIVEIRA JHG., 2004. Comparative morphology and anatomy of the leaf and stem of Peperomia dahlstedtii C.DC., Ottonia martiana Miq. and Piper diospyrifolium Kunth (Piperaceae). Gayana Botanica, vol. 61, no. 1, p. 6-17.

STEVENS, PF., 2013. Angiosperm Phylogeny Website. Version 12. Missouri Botanical Garden. Available from: $<$ http://www. mobot.org/MOBOT/research/APweb/>. Access in: 20 Jun. 2013.

TABARELLI, M. and MANTOVANI, W., 1999. Clareiras naturais e a riqueza de espécies pioneiras em uma floresta atlântica montana. Brazilian Journal of Biology, vol. 59, no. 2, p. 251-261.

TAKEMORI, NK., BONA, C. and ALQUINI, Y., 2003. Anatomia comparada das folhas de espécies de Peperomia (Piperaceae) - I. Ontogênese do tecido aqüífero e dos estômatos. Acta Botanica Brasilica, vol. 17, no. 3, p. 387-394.

VIANNA, WO. and AKISUE, G., 1997. Caracterização morfológica de Piper aduncum L. Lecta, vol. 15, no. 1-2, p. 11-62.

YUNCKER, TG., 1973. The Piperaceae of Brazil - II. Hoehnea, vol. 3, p. 29-284. 